\title{
A mechanism for revising accreditation standards: a study of the process, resources required and evaluation outcomes
}

\author{
David Greenfield ${ }^{1 *}$, Mike Civil $^{2}$, Andrew Donnison², Anne Hogden ${ }^{1}$, Reece Hinchcliff ${ }^{1}$, Johanna Westbrook ${ }^{3}$ \\ and Jeffrey Braithwaite
}

\begin{abstract}
Background: The study objective was to identify and describe the process, resources and expertise required for the revision of accreditation standards, and report outcomes arising from such activities.

Methods: Secondary document analysis of materials from an accreditation standards development agency. The Royal Australian College of General Practitioners' (RACGP) documents, minutes and reports related to the revision of the accreditation standards were examined.

Results: The RACGP revision of the accreditation standards was conducted over a 12 month period and comprised six phases with multiple tasks, including: review methodology planning; review of the evidence base and each standard; new material development; constructing field trial methodology; drafting, trialling and refining new standards; and production of new standards. Over 100 individuals participated, with an additional 30 providing periodic input and feedback. Participants were drawn from healthcare professional associations, primary healthcare services, accreditation agencies, government agencies and public health organisations. Their expertise spanned: project management; standards development and writing; primary healthcare practice; quality and safety improvement methodologies; accreditation implementation and surveying; and research. The review and development process was shaped by five issues: project expectations; resource and time requirements; a collaborative approach; stakeholder engagement; and the product produced. The RACGP evaluation was that participants were positive about their experience, the standards produced and considered them relevant for the sector.
\end{abstract}

Conclusions: The revision of accreditation standards requires considerable resources and expertise, drawn from a broad range of stakeholders. Collaborative, inclusive processes that engage key stakeholders helps promote greater industry acceptance of the standards.

Keywords: Accreditation, Healthcare, Standards, General practice, Research

\section{Background}

Government, quality improvement and accreditation agencies frequently engage in the development or revision of clinical and organisational standards. These are significant tasks that utilise considerable human and financial resources [1]. Different organisations produce standards according to their own processes and requirements, and it is

\footnotetext{
* Correspondence: d.greenfield@unsw.edu.au

${ }^{1}$ Centre for Clinical Governance Research, Australian Institute of Health Innovation, Faculty of Medicine, University of New South Wales, Sydney, NSW 2052, Australia

Full list of author information is available at the end of the article
}

believed that inclusive processes result in greater acceptance of the standards produced [1]. However, we do not know what might be evidence-informed practice in the development or revision of accreditation standards [2]. To date, no empirical study has been published that sought to identify the process, resources and expertise required for either of these endeavours [2]. This is a significant gap in the evidence base for the healthcare accreditation field [2-4], as accreditation programs have increasingly become an important strategy by which governments seek to regulate healthcare quality and safety $[5,6]$. There are now more 
than 44 health service accreditation programs which have been implemented in over 70 countries $[3,7]$.

The aim of this study was to identify and describe the process, resources and expertise required for, and to report evaluation outcomes from, a revision of a set of healthcare accreditation standards. The standards and associated revision activities under examination concern the Standards for General Practice (4th Edition) developed and revised by The Royal Australian College of General Practitioners (RACGP), which are used for accrediting general practice nationally. Through implementing an instrumental case study [8,9] of the RACGP accreditation standards we sought to highlight the process, resource and expertise issues relevant for other accreditation standard setting bodies. The RACGP is representative of other bodies that similarly have responsibility for the development and revision of standards, but do not themselves apply or assess services using the standards [10]. Previous studies have revealed the common issues and challenges facing standard setting and accreditation bodies $[7,11]$.

\section{Methods}

\section{Study context}

The Accreditation Collaborative for the Conduct of Research, Evaluation and Designated Investigations through Teamwork (ACCREDIT) was funded across 2011-15 to investigate health service accreditation in Australia [12]. The collaboration comprises university researchers, accreditation agency personnel and staff from leading quality improvement bodies in Australia (Table 1). The collaboration was awarded an Australian Research Council Linkage Project grant (LP100200586) in 2010. Ethics approval for the study was given by the University of New South Wales (UNSW) Human Research Ethics Committee (approval number HREC 10274). The ACCREDIT study protocols are publically available [12-15] and are informed by previous accreditation research conducted by UNSW and The Australian Council on Healthcare Standards (ACHS) [10-12,16-24], including reviews of the healthcare accreditation literature [2-4].

\section{Table 1 ACCREDIT collaborative partners}

\begin{tabular}{|c|c|}
\hline Partner category & Organisations \\
\hline University researchers & $\begin{array}{l}\text { - Centre for Clinical Governance Research, and } \\
\text { Centre for Health Systems and Safety Research, } \\
\text { in the Australian Institute of Health Innovation } \\
\text { at The University of New South Wales }\end{array}$ \\
\hline \multirow[t]{3}{*}{ Accreditation agencies } & - Australian General Practice Accreditation Limited \\
\hline & - Aged Care Standards and Accreditation Agency \\
\hline & - The Australian Council on Healthcare Standards \\
\hline \multirow[t]{2}{*}{$\begin{array}{l}\text { Quality improvement } \\
\text { bodies }\end{array}$} & $\begin{array}{l}\text { - Australian Commission on Safety and Quality } \\
\text { in Health Care }\end{array}$ \\
\hline & - New South Wales Clinical Excellence Commission \\
\hline
\end{tabular}

\section{Setting}

Australia has over 7,100 general practices in which more than 23,500 doctors work. There were 125 million consultation services provided during 2010-11, costed at A $\$ 5.3$ billion through the Medicare Benefits Scheme [25] (this excludes out of pocket expenses of patients). In 2011-12 there were over 4000 general practices accredited against the RACGP Standards for General Practice [26]. The standards cover five areas: practice services (7 standards and 19 criteria); rights and needs of patients (1 standard and 3 criteria); safety, quality improvement and education ( 2 standards and 7 criteria); practice management ( 2 standards and 4 criteria); and physical factors (3 standards and 8 criteria). (See: http://www.racgp.org.au/ your-practice/standards/standards4thedition/).

\section{Study methodology}

An expert group was formed by UNSW researchers and RACGP staff. During 2012, they collaboratively conducted a study with three stages. First, informed by the accreditation and evaluation literatures, the expert group purposedesigned an analysis framework with seven categories including: phase, task, objective, time frame, components, people involved and National Expert Committee Standards for General Practice (NEC-SGP) involvement. The role of the NEC-SGP includes developing and maintaining standards for general practices, and ensuring that the standards reflect quality practice and are independent of government policies and initiatives. The NEC-SGP comprises experts in standards development with professional backgrounds including general practitioners, practice nurses and managers, and a consumer representative. Since 2011 the NEC-SGP is known as the National Standing Committee - Standards for General Practice. Second, using the framework, thematic analysis [8] of RACGP documents, minutes and evaluation reports related to the revision of the accreditation standards was conducted. More than 50 documents were accessed from the RACGP information system. Third, the group reviewed the findings to clarify the process, resources and expertise utilised, and reported evaluation outcomes. Over several months the expert group discussed the findings in meetings and electronic forums to work through the material, with differences resolved by negotiation [8].

\section{Results}

The analysis framework facilitated the identification of a standards review process comprising six sequential and overlapping phases with multiple components (Table 2). The six phases occurred over a 12 month period across 2009-10. Phase 1 comprised the 'review methodology planning' phase, which occurred over two months. This phase involved two tasks: developing the review feedback 
Table 2 Analysis of the review process for the RACGP Standards for general practices (4th edition)

\begin{tabular}{|c|c|c|c|c|c|c|}
\hline Phase & Task & Objective(s) & $\begin{array}{l}\text { Time } \\
\text { frame }\end{array}$ & Components & People involved & $\begin{array}{l}\text { National Expert Committee - } \\
\text { Standards for General Practice } \\
\text { (NEC-SGP) involvement }\end{array}$ \\
\hline \multirow[t]{8}{*}{$\begin{array}{l}1 \text { Development of } \\
\text { review methodology } \\
\text { and tools }\end{array}$} & \multirow[t]{4}{*}{$\begin{array}{l}\text { Develop the review } \\
\text { feedback methodology } \\
\text { and tools }\end{array}$} & $\begin{array}{l}\text { Develop methodology to } \\
\text { collect feedback from } \\
\text { members and stakeholders on } \\
\text { current standards }\end{array}$ & \multirow[t]{4}{*}{$\begin{array}{l}1 / 09 / 09- \\
30 / 10 / 09\end{array}$} & Review methodology of previous standards review & Senior Project Officer & Review documentation and meet \\
\hline & & $\begin{array}{l}\text { Develop method of collection } \\
\text { and analysis of feedback }\end{array}$ & & Review and update draft tools & Secretariat & $\begin{array}{l}\text { Decide on accepted review } \\
\text { methodology (October) }\end{array}$ \\
\hline & & & & \multirow[t]{2}{*}{ Recommend to NEC-SGP review methodology } & Project Manager & $\begin{array}{l}\text { Recommend review methodology } \\
\text { to RACGP Council (November) }\end{array}$ \\
\hline & & & & & NEC-SGP (5) & $\begin{array}{l}\text { RACGP Council ratify review } \\
\text { methodology }\end{array}$ \\
\hline & \multirow[t]{4}{*}{$\begin{array}{l}\text { Review the evidence } \\
\text { base for current } \\
\text { method of standards } \\
\text { development }\end{array}$} & \multirow[t]{4}{*}{$\begin{array}{l}\text { Ensure development of the } \\
\text { new standards are supported } \\
\text { by latest evidence }\end{array}$} & \multirow[t]{4}{*}{$\begin{array}{l}\text { 1/09/09- } \\
30 / 10 / 09\end{array}$} & $\begin{array}{l}\text { Literature search of methods of standards } \\
\text { development and assessment }\end{array}$ & Senior Project Officer & $\begin{array}{l}\text { Secretariat provide } \\
\text { recommendations to NEC-SGP on } \\
\text { methodology of standards devel- } \\
\text { opment (October meeting) }\end{array}$ \\
\hline & & & & $\begin{array}{l}\text { Recommendations to NEC-SGP on how to develop } \\
\text { and assess standards }\end{array}$ & Secretariat & $\begin{array}{l}\text { NEC-SGP reviews evidence and } \\
\text { accept recommendations on } \\
\text { methodology of standards } \\
\text { development (October meeting) }\end{array}$ \\
\hline & & & & \multirow[t]{2}{*}{ Council acceptance of methodology, timeline and cost } & Project Manager & $\begin{array}{l}\text { NEC-SGP recommends } \\
\text { methodology, timeline and budget } \\
\text { required to RACGP Council }\end{array}$ \\
\hline & & & & & NEC-SGP (5) & $\begin{array}{l}\text { RACGP Council ratifies } \\
\text { methodology of standards } \\
\text { development process and } \\
\text { approves budget (November } \\
\text { meeting) }\end{array}$ \\
\hline \multirow[t]{7}{*}{$\begin{array}{l}2 \text { Reviewing the } \\
\text { evidence base and } \\
\text { the current standards }\end{array}$} & \multirow[t]{3}{*}{$\begin{array}{l}\text { Review the evidence } \\
\text { base for current } \\
\text { standards }\end{array}$} & \multirow[t]{3}{*}{$\begin{array}{l}\text { Ensure new edition includes } \\
\text { material that is supported by } \\
\text { latest evidence }\end{array}$} & \multirow[t]{3}{*}{$\begin{array}{l}1 / 09 / 09- \\
31 / 12 / 09\end{array}$} & Literature search of each criteria in current edition & Senior Project Officer & $\begin{array}{l}\text { NEC-SGP decide on inclusion or } \\
\text { exclusion of current criteria based } \\
\text { on evidence presented (January } \\
2010 \text { meeting) }\end{array}$ \\
\hline & & & & \multirow{2}{*}{$\begin{array}{l}\text { Recommendations to NEC-SGP on latest trends relat- } \\
\text { ing to each criteria's relevance to the next edition }\end{array}$} & Secretariat & \multirow{2}{*}{$\begin{array}{l}\text { Decide on membership of } \\
\text { subcommittees and chairs; } \\
\text { methodology and tools; new } \\
\text { material (e.g. e-health, govern- } \\
\text { ance, IC, present material) }\end{array}$} \\
\hline & & & & & NEC-SGP (5) & \\
\hline & \multirow[t]{4}{*}{$\begin{array}{l}\text { Review the current } \\
\text { standards }\end{array}$} & $\begin{array}{l}\text { All feedback on current edition } \\
\text { is considered }\end{array}$ & \multirow[t]{4}{*}{$\begin{array}{l}1 / 10 / 09- \\
31 / 01 / 10\end{array}$} & $\begin{array}{l}\text { Review feedback collected by RACGP since release } \\
\text { of current edition }\end{array}$ & Project Manager & \multirow[t]{4}{*}{$\begin{array}{l}\text { Secretariat provides analysis of } \\
\text { feedback to subcommittees }\end{array}$} \\
\hline & & \multirow[t]{3}{*}{$\begin{array}{l}\text { New material for possible } \\
\text { inclusion in revised edition is } \\
\text { identified }\end{array}$} & & $\begin{array}{l}\text { Collection of feedback from members and } \\
\text { stakeholders via focus groups, online surveys and } \\
\text { written submissions }\end{array}$ & \multirow[t]{3}{*}{ Secretariat } & \\
\hline & & & & Analysis of feedback & & \\
\hline & & & & $\begin{array}{l}\text { Recommendations to NEC-SGP and subcommit- } \\
\text { tees on material identified from formal feedback }\end{array}$ & & \\
\hline
\end{tabular}


Table 2 Analysis of the review process for the RACGP Standards for general practices (4th edition) (Continued)

\begin{tabular}{|c|c|c|c|c|c|c|}
\hline \multirow[t]{6}{*}{$\begin{array}{l}3 \text { New material } \\
\text { development }\end{array}$} & \multirow[t]{6}{*}{$\begin{array}{l}\text { Develop new material } \\
\text { for new standards }\end{array}$} & \multirow[t]{6}{*}{$\begin{array}{l}\text { Material included in new } \\
\text { edition is evidence based }\end{array}$} & \multirow[t]{6}{*}{$\begin{array}{l}1 / 11 / 09- \\
31 / 03 / 10\end{array}$} & $\begin{array}{l}\text { New material is matched with evidence - literature } \\
\text { search relating to new material }\end{array}$ & Senior Project Officer & Secretariat draft new material \\
\hline & & & & \multirow[t]{5}{*}{$\begin{array}{l}\text { New criteria, indicators and explanatory material } \\
\text { are drafted }\end{array}$} & Senior Project Officer & $\begin{array}{l}\text { Sub committees recommend } \\
\text { changes to drafts, approve draft } \\
\text { of new material and make } \\
\text { recommendations to NEC-SGP }\end{array}$ \\
\hline & & & & & Project Manager & $\begin{array}{l}\text { NEC-SGP accept recommendations } \\
\text { of sub committees }\end{array}$ \\
\hline & & & & & Senior Project Officer & $\begin{array}{l}\text { NEC-SGP approve draft of new } \\
\text { material for trial }\end{array}$ \\
\hline & & & & & Working groups & \multirow{2}{*}{$\begin{array}{l}\text { NEC-SGP recommend draft to } \\
\text { RACGP Council for endorsement } \\
\text { for trial }\end{array}$} \\
\hline & & & & & Secretariat & \\
\hline \multirow[t]{5}{*}{$\begin{array}{l}4 \text { Develop field trial } \\
\text { methodology }\end{array}$} & \multirow[t]{5}{*}{$\begin{array}{l}\text { Develop field trial } \\
\text { methodology }\end{array}$} & \multirow[t]{5}{*}{$\begin{array}{l}\text { Prepare field trial of revised } \\
\text { standards }\end{array}$} & \multirow[t]{5}{*}{$\begin{array}{l}1 / 1 / 10- \\
28 / 2 / 10\end{array}$} & $\begin{array}{l}\text { Methodology of field trial of new material is } \\
\text { described }\end{array}$ & Senior Project Officer & $\begin{array}{l}\text { Secretariat design trial } \\
\text { methodology and tools }\end{array}$ \\
\hline & & & & \multirow[t]{4}{*}{ Trial tools are developed } & GP research expert & $\begin{array}{l}\text { Subcommittee approve to } \\
\text { methodology and tools }\end{array}$ \\
\hline & & & & & Secretariat & $\begin{array}{l}\text { Subcommittees recommend } \\
\text { methodology and tools to NEC- } \\
\text { SGP }\end{array}$ \\
\hline & & & & & \multirow[t]{2}{*}{ NEC-SGP (5) } & $\begin{array}{l}\text { NEC-SGP approve trial } \\
\text { methodology (April meeting) }\end{array}$ \\
\hline & & & & & & $\begin{array}{l}\text { NEC-SGP recommend } \\
\text { methodology and tools to RACGP } \\
\text { Council (April meeting) }\end{array}$ \\
\hline \multirow[t]{5}{*}{$\begin{array}{l}5 \text { Drafting, trials and } \\
\text { feedback about the } \\
\text { new standards }\end{array}$} & \multirow[t]{5}{*}{$\begin{array}{l}\text { Seek feedback, trial and } \\
\text { refine draft new } \\
\text { standards }\end{array}$} & \multirow[t]{5}{*}{$\begin{array}{l}\text { Ensuring new edition of } \\
\text { standards meet needs of } \\
\text { RACGP and stakeholders }\end{array}$} & \multirow[t]{5}{*}{$\begin{array}{l}1 / 4 / 10- \\
31 / 8 / 10\end{array}$} & $\begin{array}{l}\text { First line feedback groups provide an early } \\
\text { indication of the feasibility and acceptability of } \\
\text { proposed explanatory material and indicators to } \\
\text { the working parties }\end{array}$ & $\begin{array}{l}\text { Accreditation agencies } \\
\text { (participant numbers } \\
\text { not specified) }\end{array}$ & $\begin{array}{l}\text { Subcommittees approve changes } \\
\text { and recommend penultimate } \\
\text { version to NEC-SGP }\end{array}$ \\
\hline & & & & $\begin{array}{l}\text { On line survey for participation by all interested } \\
\text { general practice professionals }\end{array}$ & Project Manager & $\begin{array}{l}\text { NEC-SGP approves penultimate } \\
\text { draft (July meeting) }\end{array}$ \\
\hline & & & & Written submissions & Senior Project Officer & $\begin{array}{l}\text { NEC-SGP recommends final } \\
\text { Standards to RACGP Council for } \\
\text { endorsement }\end{array}$ \\
\hline & & & & Focus groups & Secretariat & \multirow{2}{*}{$\begin{array}{l}\text { RACGP Council endorses } \\
\text { Standards (August meeting) }\end{array}$} \\
\hline & & & & $\begin{array}{l}\text { Trialling of draft standards through field trial (only } \\
\text { new Criterion to be tested) }\end{array}$ & NEC-SGP (5) & \\
\hline \multirow{4}{*}{$\begin{array}{l}6 \text { Standard } \\
\text { document revision } \\
\text { and production }\end{array}$} & \multirow{4}{*}{$\begin{array}{l}\text { Format, produce and } \\
\text { launch new standards }\end{array}$} & \multirow{4}{*}{$\begin{array}{l}\text { New edition of standards are } \\
\text { produced and released to the } \\
\text { sector }\end{array}$} & \multirow{4}{*}{$\begin{array}{l}1 / 9 / 10- \\
4 / 10 / 10\end{array}$} & Ensure formatting of new standards is correct & Project Manager & \multirow{4}{*}{$\begin{array}{l}\text { NEC-SGP members, secretariat } \\
\text { and key stakeholders present at } \\
\text { launch }\end{array}$} \\
\hline & & & & New standards are launched during ASC 2010 & Senior Project Officer & \\
\hline & & & & Online version is made available & Publications/ IT & \\
\hline & & & & Complimentary copies sent to key stakeholders & Secretariat & \\
\hline
\end{tabular}


methodology and tools; and reviewing the evidence base for information on methods of standards development. The review of the evidence base and current standards were the tasks that formed Phase 2, which was completed over a five month period. Following Phase 1, and overlapping with Phase 2, Phase 3 was a five month activity requiring the development of new material for the new standards. The construction of field trial methodology, the sole task in Phase 4, occurred in parallel and was completed in two months. The completion of the initial four phases led to Phase 5 and the combined task of drafting, trailing and refining the new standards, which occupied five months. To complete the project, the final task was the formatting and production of the new standards. This was Phase 6 and occurred over a two month period.

Over 100 individuals substantively participated in the review process, with an additional 30 providing periodic input and feedback. Participants were drawn from general practice stakeholders, including: healthcare professional associations; primary healthcare services; accreditation agencies; government agencies; and public health organisations. Their expertise spanned the fields of: project management; standards development and writing; primary healthcare practice; quality and safety improvement methodologies; accreditation implementation and surveying; and research methodologies.

The review and development process was shaped by five factors. First, identifying and delivering upon the requirements of the RACGP, and stakeholders associated with the standards, was reported as necessary for the credibility of the product. Second, identifying and communicating resource and time restrictions to participants, and observers within the sector, was required to enable the review to be completed as expected. Managing expectations and employing an effective communication strategy reinforced a collaborative approach and facilitated broad stakeholder engagement with the review; these being the third and fourth issues identified as essential for a positive development process leading to the acceptance of revised standards. Finally, the review project had to deliver a well structured, clearly written, evidence based, high quality document that was consistent with previous editions. One significant improvement suggestion emerged from the evaluation: a majority of participants agreed that consideration could be given to altering the standards revision process to conduct periodic reviews and progressive updates.

\section{Discussion}

This study provides the first case-study evidence about processes invoked for the development and revision of accreditation standards [2], and lays the foundation for further work in this area $[3,4]$. The research reveals that the revision of accreditation standards is a major undertaking requiring considerable resources and expertise, drawn from a broad range of stakeholders. Industry acceptance of the standards produced was found to be related to a collaborative, inclusive process, grounded by clinical evidence and process reviews, which promoted stakeholder participation. These findings support previously reported, non-empirical assessments, of how to approach the task [1]. For other accrediting bodies the study provides three things: insight into a difficult and challenging process; encouragement to investigate and make public their own experiences; and, a template and structure to follow to undertake such forensic examinations.

The project was completed through the combined efforts, or distributed leadership [19], of more than 100 people over a 12 month period. Key influences on the review process were: project requirements and stakeholder expectations; resource and time restrictions; collaborative team approach; stakeholder engagement; and the product required. The revision process necessitated the delicate balancing of these issues to maintain cohesion and continued participation between diverse and distributed stakeholders over an extended time period. Methodological rigour, as recognised by the six phases, was applied by the RACGP in the development, piloting and revision of materials. The commitment and effort of agency staff and committee members, who efficiently used resources with strict time constraints, enabled the efficient completion of the project. RACGP evaluation showed that stakeholder acceptance of the revision process and the revised standards produced was based on their perception of a transparent, inclusive and rigorous process implemented by the College [1].

\section{Conclusion}

The revision of accreditation standards requires collaboration from a diverse range of professionals, with considerable resources and expertise. The collaborative, inclusive process employed engaged stakeholders and promoted the acceptance of the revised standards by the sector.

\section{Competing interests}

The authors declare that they have no competing interests regarding the publication of this article.

\section{Authors' contributions}

$\mathrm{DG}, \mathrm{RH}$, JW and JB conceived of the study, and participated in its design and coordination and helped to draft the manuscript. AD participated in the data collection and analysis, and along with $\mathrm{AH}$ and $\mathrm{MC}$ assisted in the revising of the manuscript. All authors read and approved the final manuscript.

\section{Acknowledgements}

This research was supported under Australian Research Council's Linkage Projects funding scheme (project number LP100200586). The RACGP staff and members of the National Standing Committee - Standards for General Practice are thanked for access to documentation and contribution to this study. We also recognise our national and international collaborators for their contributions to the ACCREDIT project. 


\section{Author details}

${ }^{1}$ Centre for Clinical Governance Research, Australian Institute of Health Innovation, Faculty of Medicine, University of New South Wales, Sydney, NSW 2052, Australia. ${ }^{2}$ Chair National Standing Committee - Standards for General Practice, The Royal Australian College of General Practitioners, Melbourne, Australia. ${ }^{3}$ Centre for Health Systems and Patient Safety Research, Australian Institute of Health Innovation, University of New South Wales, Paddington, NSW, Australia.

Received: 7 February 2014 Accepted: 27 October 2014

Published online: 21 November 2014

\section{References}

1. McGlynn E, Shekelle P, Hussey P: Developing, Disseminating and Assessing Standards for the National Health Service: An Assessment of Current Status and Opportunities for Improvement. RAND Health; 2008.

2. Greenfield D, Pawsey M, Hinchcliff R, Moldovan M, Braithwaite J: The standard of healthcare accreditation standards: a review of empirical research underpinning their development and impact. BMC Health Serv Res 2012, 12:329.

3. Greenfield D, Braithwaite J: Health sector accreditation research: a systematic review. Int J Qual Health Care 2008, 20(3):172-183.

4. Hinchcliff R, Greenfield D, Moldovan M, Pawsey M, Mumford V, Westbrook J, Braithwaite J: Narrative synthesis of health service accreditation literature. BMJ Qual Saf 2012, 21:979-991.

5. Australian Commission on Safety and Quality in Health Care: National Safety and Quality Health Service Standards. Sydney, Australia: Commonwealth of Australia; 2011.

6. Access to Standards. [www.accreditation.ca/review-our-standards]

7. Braithwaite J, Shaw C, Moldovan M, Greenfield D, Hinchcliff R, Mumford V, Kristensen M, Westbrook J, Nicklin W, Fortune T, Whittaker S: Comparison of health service accreditation in low- and middle-income countries with those in higher income countries: a cross sectional study. Int J Qual Health Care 2012, 24(6):568-577.

8. Liamputtong P: Qualitative Research Methods. 3rd edition. Melbourne: Oxford University Press; 2009.

9. Creswell J: Qualitative Inquiry and Research Design: Choosing Among Five Approaches. London: Sage Publications; 2007

10. Greenfield D, Pawsey M, Braithwaite J: Accreditation: A Global Regulatory Mechanism to Promote Quality and Safety. In Continuous Quality Improvement in Health Care. 4th edition. Edited by Sollecito W, Johnson J. New York: Jones and Barlett Learning; 2013:513-531.

11. Greenfield D, Pawsey M, Braithwaite J: The role and impact of accreditation on the healthcare revolution. O papel e o impacto da acreditação na revolução da atenção à saúde. Acreditação 2012, 1(2):1-14.

12. Braithwaite J, Westbrook J, Johnston B, Clark S, Brandon M, Banks M Hughes C, Greenfield D, Pawsey M, Corbett A, Georgiou A, Callen J, Øvretveit J, Pope C, Suñol R, Shaw C, Debono D, Westbrook M, Hinchcliff R, Moldovan M: Strengthening organizational performance through accreditation research: the ACCREDIT project. BMC Res Notes 2011, 4:390

13. Greenfield D, Hinchcliff R, Moldovan M, Mumford V, Pawsey M, Westbrook JJB, Braithwaite J: A multi-method research investigation of consumer involvement in Australian health service accreditation programs: the ACCREDIT-SCI study protocol. BMJ Open 2012, 2:329.

14. Hinchcliff R, Greenfield D, Moldovan M, Pawsey M, Mumford V, Westbrook $J J B$, Braithwaite J: Evaluation of current Australian health services accreditation processes (ACCREDIT-CAP): a protocol for a mixed method research project. BMJ Open 2012, 0:e001726.

15. Mumford V, Greenfield D, Hinchcliff R, Moldovan M, Forde K, Westbrook J, Braithwaite J: Economic evaluation of Australian acute care accreditation (ACCREDIT-CBA [acute]): study protocol for a mixed-method research project. BMJ Open 2013, 3:e002381.

16. Braithwaite J, Greenfield D, Westbrook J, Pawsey M, Westbrook M, Gibberd R, Naylor J, Nathan S, Robinson M, Runciman B, Jackson M, Travaglia J, Johnston B, Yen D, McDonald H, Low L, Redman S, Johnson B, Corbett A, Hennessy D, Clark J, Lancaster J: Health service accreditation as a predictor of clinical and organisational performance: a blinded, random, stratified study. Qual Saf Health Care 2010, 19(1):14-21.

17. Greenfield D, Braithwaite J: Developing the evidence base for accreditation of healthcare organizations: a call for transparency and innovation. Qual Saf Health Care 2009, 18:162-163.
18. Greenfield D, Braithwaite J, Pawsey M: Health care accreditation surveyor styles typology. Int J Health Care Qual Assur 2008, 21(5):435-443.

19. Greenfield D, Braithwaite J, Pawsey M, Johnson B, Robinson M: Distributed leadership to mobilise capacity for accreditation research. $J$ Health Organ Manage 2009, 23(2):255-267.

20. Greenfield D, Hinchcliff R, Westbrook M, Jones D, Low L, Johnston B, Banks M, Pawsey M, Moldovan M, Westbrook J, Braithwaite J: An empirical test of accreditation patient journey surveys: randomised trial. Int J Qual Health Care 2012, 24(5):495-500

21. Greenfield D, Moldovan M, Westbrook M, Jones D, Low L, Johnston B, Clark S, Banks M, Pawsey M, Hinchcliff R, Westbrook J, Braithwaite J: An empirical test of short notice surveys in two accreditation programs. Int J Qual Health Care 2012, 24(1):65-71.

22. Greenfield D, Pawsey M, Braithwaite J: What motivates health professionals to engage in the accreditation of healthcare organizations? Int J Qual Health Care 2011, 23(1):8-14.

23. Greenfield D, Pawsey M, Naylor J, Braithwaite J: Are accreditation surveys reliable? Int J Health Care Qual Assur 2009, 22(2):105-116.

24. Greenfield D, Pawsey M, Naylor J, Braithwaite J: Researching the reliability of accreditation survey teams: lessons learnt when things went awry. Health Inform Manage 2013, 42(1):4-10.

25. Australian Institute of Health and Welfare: Australia's Health 2012. Canberra: Australian Institute of Health and Welfare; 2012.

26. Australian General Practice Accreditation Limited and Quality in Practice: Australian General Practice Accreditation Limited and Quality in Practice Pty Ltd Annual Report. Brisbane: 2012.

doi:10.1186/s12913-014-0571-8

Cite this article as: Greenfield et al: A mechanism for revising accreditation standards: a study of the process, resources required and evaluation outcomes. BMC Health Services Research 2014 14:571.

\section{Submit your next manuscript to BioMed Central and take full advantage of:}

- Convenient online submission

- Thorough peer review

- No space constraints or color figure charges

- Immediate publication on acceptance

- Inclusion in PubMed, CAS, Scopus and Google Scholar

- Research which is freely available for redistribution

Submit your manuscript at www.biomedcentral.com/submit
C) Biomed Central 